Provided for non-commercial research and education use. Not for reproduction, distribution or commercial use.

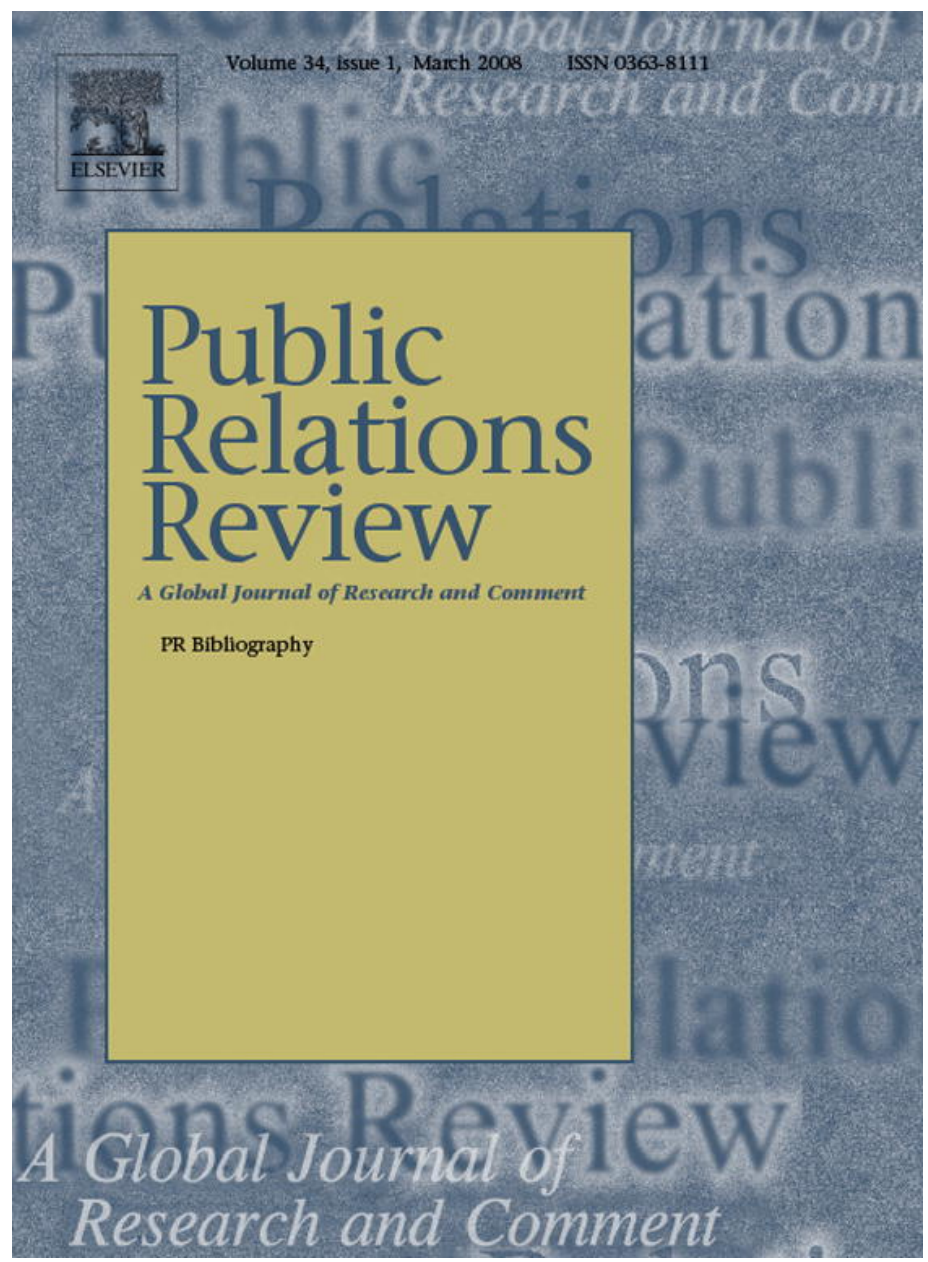

This article was published in an Elsevier journal. The attached copy

is furnished to the author for non-commercial research and education use, including for instruction at the author's institution, sharing with colleagues and providing to institution administration.

Other uses, including reproduction and distribution, or selling or licensing copies, or posting to personal, institutional or third party websites are prohibited.

In most cases authors are permitted to post their version of the article (e.g. in Word or Tex form) to their personal website or institutional repository. Authors requiring further information regarding Elsevier's archiving and manuscript policies are encouraged to visit: 


\title{
Creating the cult of a saint: Communication strategies in 10th century England
}

\author{
Tom Watson* \\ The Media School, Bournemouth University, Talbot Campus, Poole, Dorset BH12 5BB, United Kingdom
}

Received 10 May 2007; received in revised form 10 August 2007; accepted 21 August 2007

\begin{abstract}
In late 10th century England, a little-known and long-dead bishop named Swithun was canonised and became one of the mostwidely culted saints in the country. Behind the creation of the cult of Saint Swithun were communication and political strategies with aspects of brand creation and extension, fund-raising, message creation and delivery, and stakeholder engagement using tactics such as word-of-mouth, the creation of special events and music, and use of specially commissioned publications. Using the prism of modern public relations practice and theory, the creation and maintenance of this important saintly cult is reviewed.

(C) 2007 Elsevier Inc. All rights reserved.
\end{abstract}

Keywords: Communication strategy; Political communication; Public relations; Religious communication

"If it rains on St Swithun's Day (July 15), it will rain for forty days"—an ancient English proverb.

\section{Introduction}

In public relations literature, the formation of the discipline in an organised manner is generally seen as an early 20th century phenomena (Wilcox, Cameron, Ault, \& Agee, 2005, chap. 1), although the antecedents are "virtually as old as human civilization" (Heath \& Coombs, 2006, p. 45, chap. 2). There are examples of reputation building such as great displays and games in Imperial Rome, the fairs and jousts of medieval England and religious events. The example of Pope Urban II promoting the crusades in 1095 is also identified as an example of communicating through networks, by invoking higher rewards and offering the opportunity to visit holy shrines (Newsom, VanSlyke Turk, \& Kruckeberg, 2004, chap. 2). In this article, religious communication is explored as an exemplar of early public relations strategy and tactics. Heath and Coombs (2006, chap. 2) say:

Pilgrimages may be treated as public relations. Masses of faithful coming to worship can be viewed as public relations. Propagating the faith through preaching and the construction of churches - that too may be public relations. Songs and sermons conveyed messages of faith. Paintings and statues were crafted to inspire faith. (p. 45)

\footnotetext{
* Tel.: +44 1202 965140; fax: +44 1202965530 .

E-mail address: twatson@bournemouth.ac.uk.
} 
In the broad sense of public relations being about managing relations with publics (Grunig \& Hunt, 1984), religious activity is about communication and retention of audiences, and the creation of loyalty using word-of-mouth messaging, group activities, publications and personal contact. It invokes notions of mystery, celebrity (the appeal of saints) and tradition to engender support, and operates with authority. It was not, however, seen as strategically planned activity in medieval times and, of course, religious communication and events did not use the framing of language and accumulated best practice that are applied now. Yet, using the example of the formation of the cult of St Swithun in 10th century England, this article will argue that the church leaders of that time used organisational and political communication strategies that had aspects of brand creation and extension, fund-raising, message creation and delivery, and stakeholder engagement using tactics such as word-of-mouth, the creation of special events and music, and the use of specially commissioned publications. There was a body of best practice that had been developed over 500 years before being implemented in this instance, while the communication programme was undertaken on a very long-term basis, lasting 567 years before the cult ended. Although the term "public relations" was not used, the activity was undertaken in a strong persuasional manner. All that was lacking, though, were the methods of modern mass communication.

\section{Methodology}

The story of St Swithun and the formation of his cult by Bishop Aethelwold of Winchester using strategies and tactics that are recognisable to modern public relations practitioners are best told as a chronological historical narrative. Bertrand and Hughes (2005, chap. 6) argue that "the major strength of historical narrative is its capacity to bring the past to life for a reader" (p. 117), although there are risks in presenting evidence as finite and absolute. In the case of a 10th century case study, scholarship and secondary sources must be relied upon, as few contemporary sources are available. As so much of the scholarship on St Swithun, Aethelwold and the church of that time, including translations of Latin and Old English documents from the principal writers of the 10th century, is contained within Michael Lapidge's The Cult of St Swithun (Lapidge, 2003, chaps. 1-4), it will be referred to extensively. All references to the contemporary writers, including Aelfric, Lantfred and Wulfstan are drawn from this splendid and comprehensive book.

\section{Saint Swithun}

Swithun (St Swithun), who died in 863, was bishop of Winchester and "is better known for his activities as a miracleworking saint than for his tenure of episcopal office" (Yorke, 2004b, p. 1). Little information about him survives other than connections with the Anglo-Saxon royal family, which was based in the principal city of Winchester, and his interest in that city. In view of reforms of the English church that were to follow in the 10th century, it is important to note that Swithun was a secular cleric and not a member of a monastic order.

According to the earliest hagiography, Vita Sancta Swithuni (Life of St Swithun) probably written by a cleric at nearby Sherborne in the late 11th century, Swithun was a pious and exceedingly humble man. Other records and accounts indicate that he was a cleric promoted within the church and the tutor to the future King Aethelwulf who later appointed him as Bishop of Winchester at the end of October 852. He repaired several dilapidated churches in the diocese and a tenth century poem "stated that Swithun constructed a bridge at the East Gate of Winchester in 859" (Lapidge, 2003, p. 7, chaps. 1-4). After he died on July 2, 863, he was buried in a sarcophagus on open ground between the western entrance to the Old Minster in Winchester and a stone cross dedicated to St Martin. The position of the tomb can be seen in outline on ground by the northern side of Winchester Cathedral.

In the centuries following the translation of his remains into the Old Minister 108 years later on 15 July, 971, St Swithun became one of the best-known and most widely culted Anglo-Saxon saints, both in England and on the Continent. But of the saint's career on this earth, by contrast, very little is known. Even the details from Vita Sancta Swithuni are of doubtful validity and Lapidge calls it as "a work of pure fiction - the creation of a scholar who had few historical resources at his disposal" (2003, p. 69, chaps. 1-4). After his death, it appears by his absence from contemporary writings that Swithun was ignored and the tomb was little regarded, despite its position by the entrance to the Old Minster, then the most important church in Winchester and thus in England because of its association with the royal court.

Although Yorke says that "choice of this site [of the tomb] was a sign of his humility as he wanted people to walk over his grave" (Yorke, 2004b, p. 2), Lapidge says that "all of these conjectures are more or less plausible; though none of them can be verified. One conjecture, however, is utterly implausible: namely that Swithun in humility sought an 
inconspicuous burial place. On the contrary, he was buried in a highly prominent position, his tomb marked by a stone cross and covered by a house-shaped tomb-structure which lay immediately outside the west door of the Old Minster" (2003, p. 7, chaps. 1-4). He adds that "it was the prominence and position of the tomb which in the late 960s suggested to Bishop Aethelwold and his advisers the possibility of translating Swithun's remains into the Old Minster itself, and making them the focus of a new cult" (2003, p. 7).

So, around 99 years after his death, Swithun suddenly became an important element in a campaign by Aethelwold, one of his successors as Bishop of Winchester, to radically reform the Anglo-Saxon church. Along with Dunstan and Oswald in other parts of England, Aethelwold, a Benedictine monk, took the church in a more religiously rigorous and monastic direction. In 964, with the full support of King Edgar, he had sent an armed force into Winchester's two major churches and expelled all the secular clerics at the points of spears and swords and replaced them with monks. This widely resented move had been agreed with the Pope in the previous year, but had been kept secret (Yorke, 2004a, p. 2). In order to maintain his ecclesiastical leadership and appease the ejected clerics, Bishop Aethelwold developed a campaign to promote a cult of St Swithun, who as noted earlier, was a secular cleric.

\section{The cult of St Swithun}

The cult began on July 15, 971 when Bishop Swithun's remains were lifted from the stone sarcophagus outside the Old Minster and moved inside (translated) the Old Minster. [Legend says the "translation" took place in torrential rain and is thus the source of the famous weather proverb.] It was a grand event that dwarfed all previous events of this kind as Bishop Aethelwold strove to launch the cult and complete his leadership of change in the church. "Quite simply, no translation on this scale had previously taken place in England" (Lapidge, 2003, p. 8, chaps. 1-4). Shortly after, a lavish gold and silver reliquary (tomb) to hold the saint's relics was commissioned by King Edgar and installed. It consumed $300 \mathrm{lbs}$ of gold, silver and ruby gems from the royal coffers. Obviously, it was of great value and featured work of the highest craftsmanship, being decorated with jewels and portraying scenes from the final suffering and resurrection of Jesus Christ. [There is a replica in Winchester Cathedral.] In the years that followed, Bishop Aethelwold expanded the footprint of the Old Minster on a large scale to incorporate the saint's original tomb and to make it the focal point for the saint's cult. The rebuilding was completed in 980 and made the Old Minster one of the largest church structures in the then Christian world and comparable with major churches in France, Germany and Italy.

The process of translation had a form and process that had been well defined in continental Europe from the fourth century onwards as the early Christian church sought to recognise and honour the early martyrs. In modern terminology, it was a proven strategy and a best practice model for the church. It is notable that in addition to the ecclesiastical tests, it required a high level of communication in order to gain the desired results of attendance at the saint's tomb, new sources of income and continued message transmission. The process involved "the discovery of the saint's location and miraculous power (inventio); the formal liturgical ceremony of translations (translatio); the provision of a reliquary to serve as a focal point for the cult; the reconstruction of the church in which the reliquary was housed, in order to allow increased public access to the shrine; publicity for the shrine and provision of various prayers for mass and Office needed for liturgical commemoration of the saint" (Lapidge, 2003, p. 8, chaps. 1-4). Bishop Aethelwold, although he never traveled to Europe, was well informed on ecclesiastical processes and would have modeled the translation of Bishop Swithun on these precedents. Within his diocese were fellow Benedictine monks from Ghent and Fleury in modern Belgium and France who were aware of translations and the many miracles (miracula) that occurred subsequently. "It was perhaps through discussions with continental monks ... that the idea of creating a cult-centre in Winchester, focused on a ninth century bishop who appeared to be entombed in a prominent position outside the west door of the Old Minster, first occurred to Aethelwold" (Lapidge, 2003, p. 12, chaps. 1-4).

Swithun was an unexpected choice for Aethelwold's campaign of church reform, but, it may be argued, he was a canny choice. Yorke comments "there is no evidence that Swithun had even been a monk; he was one of the secular clerks whom Aethelwold purported to despise" (Yorke, 2004b, p. 2). Yet, this campaign may be seen as an early and wellreasoned example of issues management and stakeholder engagement as it "provided a means of reconciliation with the secular clerks whom he had expelled from the Old Minster" (Yorke, 2004b, p. 2). Bishop Aethelwold went a further step and appointed one of the expelled clerics, Eadsige, to be guardian of the reliquary in the role of sacrist. On this occasion, the stakeholder engagement led to Eadsige recanting and taking monastic orders, becoming a guardian (sacristan) of Swithun's shrine and thus a personal advocate. He was followed into monastic orders by three other expelled clerics. 
Eadsige's role was a prominent position in the promulgation of the cult and a bridge between Aethelwold's monastic management of the diocese and the ousted secular clergy.

There is doubt as to when and how St Swithun's miraculous powers were first evidenced. Yorke (2004b, p. 1) refers to one incident in his lifetime when he restored broken eggs to their whole state but this does not appear to have been recorded (and with dubious validity) until Vita Sancta Swithuni was published, around 120 years after Swithun's translation and more than 220 years after his death. The main evidence for the inventio is expressed in Lantfred's Translatio et miraculo Sancta Swithuni. He wrote that they first occurred as late as 968 (105 years after his death). Bishop Swithun appeared as a vision to a blacksmith, whom he told to report his appearance to Eadsige, the expelled canon, and thence to Aethelwold. As part of the reconciliation between Aethelwold and the secular clergy, this appearance may have a reasoning that was added ex post facto. Lapidge ascribes this story to "local Winchester politics" (2003, p. 15, chaps. 1-4). The next miracle to occur was in 969 when a man suffering from the pain of a hump-back lay down by Swithun's tomb and fell asleep but awoke fully cured. There was also a third miracle of the man who suffered a paralysis after seeing the apparition of "three terrifying and naked Ethiopian women". He was told in a dream that he should go to Swithun's tomb where he was cured (Lapidge, 2003, pp. 14-15, chaps. 1-4). Once the third miracle had been ascribed to Swithun, the process of translatio went ahead with the recovery of the relics and their translation into the Old Minster.

Although there were three "miracles" that occurred shortly before the translation and the formation of the cult of St Swithun, there remains the question why this humble bishop of no great note in his lifetime was elevated ahead of other bishops of greater standing who were already entombed within the Old Minster. Lapidge acidly comments that "one cannot help thinking, perhaps cynically, that Bishop Swithun was chosen to become the focus of a new cult not because he had appeared in dreams, but because his tomb was situated in an extremely prominent position outside the west door of the Old Minster, in a direct line midway between the door and the tower of St Martin [also a prominent place of pilgrimage]. Winchester sources, such as Wulfstan and Aelfric, are unanimous and explicit in stating that nothing whatsoever was known of Swithun's life at the time of the translation" (Lapidge, 2003, pp. 15-16, chaps. 1-4).

As noted earlier, the process of cult formation and promotion proceeded onward after the sainthood had been confirmed and the remains had been moved to their new position in the Old Minster. This was the first, essential step in the strategic formation of the cult. After the construction of the reliquary, in which the saint's remains (relics) were kept, the next steps were the reconstruction of the Old Minster to handle increased pilgrim traffic, publicity and liturgical commemoration.

The church was extended westward to cover Swithun's original tomb. Aethelwold also strengthened and extended other sides to create "one of the architectural glories of Western Christendom" (Lapidge, 2003, p. 20, chaps. 1-4). This work was continued by later bishops, although in little more than a century the Old Minster would be gradually replaced from 1093 by the building that is known around the world as Winchester Cathedral and which has St Swithun as one of its patron saints.

The propagation of the cult of St Swithun was undertaken to bring new income to the diocese. By translating the remains and creating a point of pilgrimage, Aethelwold wanted to attract "substantial numbers of pilgrims (and hence of revenues) to the Old Minster, the assumption being that if a person of means receives a cure, s/he would make a contribution to the saint's church" (Lapidge, 2003, p. 21, chaps. 1-4). The pilgrims flocked to Winchester and many miracles occurred with Lantfred reporting that from his experience that 200 sick people were cured in a 10-day period.

St Swithun's shrine, supported by church-wide publicity, rapidly became a centre for pilgrimage. Contemporary writings by Lantfred and Wulfstan Cantor (an acolyte of Bishop Aethelwold) reported large numbers of miracles. Wulfstan's own preaching was frequently interrupted by calls for him to go to the Old Minster for yet another miracle. Another contemporary, Aelfric, recorded that there were many crutches and stools left by cured cripples in the Old Minster.

The attraction of pilgrims was achieved rapidly without any of the modern tools of mass communication. Publications, however, made an important contribution to message distribution and the validation of claims of miracle working at the shrine. Within a relatively short period of 20 years there were three hagiographies of St Swithun. Bishop Aethelwold commissioned them from his Winchester staff, such as Lantfred (Translatio et miracula Sancta Swithuni) and Wulfstan Cantor (Narratio metrica de Sancta Swithuno). Aelfric, the third hagiographer, edited Lantfred's bombastic text into a five-page "epitome" and wrote an Old English, Life of St Swithun. These documents were mostly written in Latin, the language of the church. They captured the story of St Swithun and made it available for dissemination among the width of the church. By offering the saint's life in Old English through Aelfric's text, the church was 
also communicating to the whole of its congregation and not only the small number who understood Latin. These documents were, however, hand-inscribed on vellum and thus not available for mass consumption. Lapidge says the principal purpose of Lantfred's Translatio et miracula Sancta Swithuni "is that of demonstrating how pilgrims were attracted, in large numbers, from far and wide, to the Old Minster once the translation had taken place" (Lapidge, 2003, p. 21, chaps. 1-4). The publications were thus used to publicise the cult and the Old Minster via targeted channels of privileged communication amongst the clergy (who could read and write) in order to spread news amongst their congregations and so attract visitors.

Word-of-mouth was the most likely way by which St Swithun's reputation as a miracle worker reached so many people in southern and central England. "Clearly people were not coming to Winchester because they had read about the saint. On the contrary, it would seem that oral report was the agency by which the saint's fame spread abroad in England and France .... Whether the church in Winchester took an active role in spreading the reports, and, if so, how, is unclear. But there is no doubt that St Swithun very quickly became one of the most widely culted saints in England" (Lapidge, 2003, p. 21, chaps. 1-4).

Other methods of supporting the promulgation and longevity of the cult, effectively modern day brand extension, were the inclusion of saints' days in church calendars, the dedication of churches to saints, the distribution of relics and the inclusion of prayers to saints within the liturgy.

As a method of reinforcing the importance of a saint and placing her or him in the mainstream of church life, their inclusion on the annual calendar of worship and celebration was vital. St Swithun has three commemorations-July 2 (deposition), July 15 (translation) and October 30 (ordination). The few remaining church calendars from the period up to 1100 show some calendar entries for the Winchester saint but after that period they become more frequent, not just in England but in northern France and in a few places in Scandinavia. Only the July 15 date remains in some church calendars although saints' days are not now widely observed in England.

At present, there are 68 churches, ancient and modern, dedicated to St Swithun in England. There are none in the other countries of the United Kingdom and none north of Wakefield in south Yorkshire. So St Swithun can be seen as a very English saint represented in the south and central parts of the country. While these are substantial numbers, Lapidge says they fall well behind dedications to the Virgin (more than 2300) and All Saints (more than 1200). The later sainted martyr St Thomas Becket has slightly more dedications, but St Swithun "compares very favourably with those for other native Anglo-Saxon saints" such as Cuthbert, Oswald, Botulf and Edmund" (Lapidge, 2003, p. 47, chaps. 1-4).

Aethelwold also ensured that the miracle worker's importance was supported in church literature as benedictions for St Swithun in the Benedictine-style liturgy that he had introduced from French monasteries. The new saint was thus part of the intensification of religious practice within the English church that this authoritarian Bishop of Winchester had driven.

As a method of propagating the cult, the distribution of the saint's relics was widely used. Whether this was considered to be a "strategy" is not known but that is what in effect it became. The situation in Winchester was this: as news of his miraculous powers became known, pilgrims flocked to the Old Minster from an ever-widening range. This led, says Lapidge (2003, p. 37, chaps. 1-4) to other churches wishing "to gain access to these powers; in order words, to have their own relics of St Swithun". It was customary for churches to have extensive collections of relics. Although there was reluctance for Winchester to distribute relics and release total control over the saint's reliquary (in which they were stored), there seems to have been some "leakage" with the first recorded dispersal being to Canterbury when Aethelwold's successor Aelfheah was elevated to the archbishopric. He took Swithun's head with him. Recent research by John Crook (reported in Lapidge, 2003, pp. 61-65, chaps. 1-4) has found that this is now at Evreux Cathedral in northern France. By the 12th century, many churches had relics and Lapidge tartly comments, "one wonders how many bones still remained in the 'Old Reliquary' at Winchester when it was melted down in 1451" (Lapidge, 2003, p. 42, chaps. 1-4). Be that as it may, the distribution of relics supported the cult of St Swithun and gave it longevity as well as accessibility to people who did not normally travel far from their home town or village in a lifetime.

The cult of St Swithun was also robust enough to survive the Norman invasion of England in 1066, which made its headquarters in Winchester. By then it would have been widely known across the Christian world as a result of Aethelwold's comprehensive publicity campaign and, of course, the reports of the miracles through the saint's intercession.

The legend attributed to St Swithun that "if it rains on St Swithun's Day (July 15), it will rain for 40 days" does not appear to have started from legendarily torrential rain on the day of his translation. It may have originally arisen from 
a prognostic couplet for the saints' days of two Roman martyrs Saints Processus and Martinianus, which was on July 2 and the same day as Swithun's deposition. Lapidge speculates (2003, pp. 48-49, chaps. 1-4) that there may have been a shift of dates from July 2 to 15 over time. In any case, it wasn't until the 16th century that the legend was ascribed to the Winchester saint and became fixed in folk memory and print. It is ironic that as the cult officially ended in 1538 when the shrine was broken up (Yorke, 2004b, p. 3), the one memorable popular reference to St Swithun arose.

\section{Conclusion}

Aethelwold's campaign to reform the 10th century Anglo-Saxon church used strategies and tactics that would be common in the 21 st century. Although he held immense power, as the Bishop of Winchester was fully supported by the King, he understood the need to engage the support of those whom he had displaced from the churches and so offered them a saintly symbol of secular clerical miracle-working. Over time, he created a brand of the cult of St Swithun, used internal communications to promote the shrine in Winchester amongst the clergy and monastic orders, produced publications that recorded the saint's miracles and incorporated benedictions into the daily language of the church's worship. This aided dissemination of the messages and reinforced them by frequent repetition.

There is no Grunigian symmetry in the communications strategy, as this was a one-way publicity process driven by a control strategy, but Aethelwold did take note of stakeholders who were best kept within the church's ambit, no matter how disenfranchised they had become. As the church was at the heart of the political and power process in the 10th century, Aethelwold's campaign can also be considered highly successful as he achieved his aims of church reform and they have persisted in the liturgical traditional of the Catholic and Anglican/Episcopal traditions until this day. But would have Swithun have been remembered for restoring broken eggs and have become a household name without Aethelwold's need for a symbol to reinforce his change management campaign? It is highly unlikely.

\section{A patron saint for public relations?}

Aethelwold himself was later elevated to sainthood after his death in 984, following the established process of inventio and translatio. His remains were translated to the Old Minster in 996. Aethelwold's life and miracles were celebrated by Wulfstan, who became a leader of his cult, and Aelfric in Latin and Old English and all the liturgical development took place with hymns, collects, topes and mass sets, but the "cult never seems to have achieved the great popularity and was rarely celebrated beyond the foundations [church buildings] which had some personal link with the saint" (Yorke, 2004a, p. 7). Aethelwold was seen having an authoritarian rather than affectionate legacy. "Events such as the forceful expulsion of the secular clerks at the Old Minster had left a bitter taste and have given him a reputation for ruthless sensitivity which is not shared by other tenth-century reformers" (Yorke, 2004a, p. 9).

Although he appears to have been unloved in his time, Aethelwold did achieve his objectives of church reform and expansion of the Old Minster through the use of established strategies (the translation of a saint), the invoking of celebrity (the creation of the cult) and extensive communication (word-of-mouth, publications, saints' days, distribution of relics and liturgy). Perhaps he could be the patron saint of public relations.

\section{References}

Bertrand, I., \& Hughes, P. (2005). Media research methods: Audiences, institutions, texts. Basingstoke: Palgrave.

Grunig, J. E., \& Hunt, T. (1984). Managing public relations. New York: Holt, Rinehart \& Winston.

Heath, R. L., \& Coombs, W. T. (2006). Today's public relations. Thousand Oaks, CA: Sage Publications.

Lapidge, M. (2003). The cult of St Swithun: Winchester Studies 4.ii. Oxford: The Clarendon Press.

Newsom, D., VanSlyke Turk, J., \& Kruckeberg, D. (2004). This is PR (8th ed.). Belmont, CA: Thomson Wadworth.

Wilcox, D. L., Cameron, G. T., Ault, P. H., \& Agee, W. K. (2005). Public relations strategies and tactics (7th ed.). Boston: Pearson Allyn \& Bacon. Yorke, B. A. E. (2004a). Aethelwold (904x9-984), Oxford Dictionary of National Biography. Oxford: Oxford University Press.

Yorke, B. A. E. (2004b). Swithun [St Swithun] (d.863), Oxford Dictionary of National Biography. Oxford: Oxford University Press. 